\title{
Studi Higiene Sanitasi Makanan Dengan Pemeriksaan Escherichia coli Air Pencucian dan Peralatan Makan Di Pujasera X
}

\author{
Yulianti Pratama $^{1^{*}}$, Nadya Almira Rachman $^{2}$ \\ ${ }^{1,2}$ Teknik Lingkungan, Fakultas Teknik Sipil dan Perencanaan, Institut Teknologi Nasional Bandung \\ Jl. PH.H Mustofa No. 23, Bandung, 40124, Indonesia \\ *Koresponden email: yulianti@itenas.ac.id
}

Diterima : 17 Oktober 2020

Disetujui : 26 Oktober 2020

\begin{abstract}
Food sanitation is one of the methods used to protect food from contamination, maintain quality, and prevent potential bacterial transmission. This research was conducted to observe potential diseases caused by the microbiological quality of clean water for household use. MPN method was used to compare the quality of clean water based on the Peraturan Menteri Kesehatan Nomor 416 Tahun 1990. Swab method was implemented to observe the hygiene level of the cutlery to compare with the Peraturan Menteri Kesehatan Nomor 1098 Tahun 2003. 79/100 ml of total coliform found in tenant 1 and tenant 2 which means it did not meet the standards. Escherichia coli were found absent in both clean water sources. The same result comes from 2 samples of plates and spoons before and after the first usage and second usage. In tenant 2, Escherichia coli were found in plate sample no.1 before usage and the clerk's hands before serving the food. Hence, it did not meet the standards. Based on the interviews and observations, the sanitation hygiene of the clerks and the physical hygiene of tenant 1 and tenant 2 had only fulfilled $61.9 \%$ and $57.1 \%$ of proper hygiene, so it needed to be improved.
\end{abstract}

Keywords: cutlery, clean water, Escherichia coli, hygiene sanitation, total coliform

\section{Abstrak}

Sanitasi makanan merupakan salah satu cara menjaga higienis makanan sebagai upaya menjaga kualitas makanan dan mencegah potensi penularan penyakit. Penelitian ini untuk mengetahui potensi resiko penularan penyakit yang diakibatkan oleh kualitas mikrobiologis air bersih untuk pencucian menggunakan metode JPT dan membandingkan dengan Peraturan Menteri Kesehatan Nomor 416 Tahun 1990 serta peralatan makan di Pujasera X dengan metode swab dan membandingkannya dengan Peraturan Menteri Kesehatan Nomor 1098 Tahun 2003. Hasil pemeriksaan di laboratorium, air bersih di tenant 1 dan tenant 2 mengandung 79/100 ml total coliform, hal ini tidak memenuhi baku mutu. Sementara tidak ditemukan Escherichia coli pada kedua sumber air. Hasil pemeriksaan terhadap 2 sampel piring dan sendok sebelum pemakaian pertama, setelah pemakaian pertama dan setelah pemakaian kedua di tenant 1 tidak ditemukan Escherichia coli. Sementara di tenant 2 dari 8 sampel piring dan sendok, Escherichia coli ditemukan di sampel piring 1 sebelum pemakaian dan tangan penjamah sebelum melakukan penyajian, hal ini tidak sesuai dengan baku mutu. Berdasarkan hasil wawancara dan observasi, higienis sanitasi penjamah dan fisik tenant 1 dan tenant 2 masing-masing baru memenuhi $61,9 \%$ dan 57,1\% kelayakan higienis sehingga perlu untuk ditingkatkan.

Kata kunci: air bersih, Escherichia coli, higienis sanitasi, peralatan makan, total coliform

\section{Pendahuluan}

Makanan merupakan kebutuhan dasar bagi manusia, sehingga dalam proses produksi serta penyajiannya haruslah higenis karena hal tersebut sangat mempengaruhi kesehatan manusia. Sanitasi makanan merupakan salah satu cara menjaga kehigienisan makanan, dimana sanitasi makanan berupaya untuk menjaga kualitas makanan dan mencegah resiko penularan penyakit dari mulai sebelum makanan diproduksi, saat dalam proses pengolahan, penyimpanan, pengangkutan, sampai dengan makanan dan minuman siap dikonsumsi oleh konsumen. Buruknya sanitasi makanan dapat mempengaruhi kesehatan seseorang [1].

Menurut Peraturan Menteri Kesehatan Nomor 1098 Tahun 2003 Tentang Persyaratan Higiene Sanitasi Rumah Makan dan Restoran, peralatan yang kontak langsung dengan makanan yang siap disajikan tidak boleh mengandung Escherichia coli per $\mathrm{cm}^{2}$ permukaan alat [2]. Peraturan Menteri ini sepatutnya dipatuhi oleh para pemilik usaha rumah makan untuk menekan resiko timbulnya penyakit yang berasal dari peralatan makanan. Alasan Escherichia coli menjadi persyaratan utama dalam 
kehigienisan peralatan makan karena Escherichia coli merupakan indikator adanya cemaran feses manusia maupun hewan berdarah panas karena keberadaannya yang banyak dalam usus manusia dan hewan, dan indikator kemungkinan keberadaan patogen.

Selain itu, Escherichia coli merupakan bakteri yang mudah dideteksi keberadaannya [3]. Selain peralatan makan, hal lain yang perlu diperhatikan adalah air pencucian peralatan itu sendiri. Peraturan Menteri Kesehatan Nomor 416 Tahun 1990 Tentang Syarat-syarat dan Pengawasan Kualitas Air mensyaratkan jumlah total coliform untuk air bersih yang berasal dari perpipaan adalah 10 per $100 \mathrm{ml}$ dan untuk air bersih bukan perpipaan 50 per $100 \mathrm{ml}$ yang dinyatakan dalam Jumlah Perkiraan Terdekat (JPT) [4]. Kehadiran coliform dalam air mengindikasikan adanya organisme patogen.

Pujasera X merupakan salah satu tempat menjual makanan dan minuman yang berada di lingkungan kampus untuk mahasiswa, staf, dan juga umum. Berdasarkan hasil observasi dan wawancara, Pujasera X memiliki 2 tenant yang menjual aneka makanan dan minuman berupa makanan ala warteg, soto, ayam penyet, dan makanan sehari-hari lainnya. Oleh karena itu, penelitian ini dilakukan di Pujasera $\mathrm{X}$ ini karena letaknya yang berada di lingkungan kampus. Penelitian dilakukan untuk melihat adanya kontaminasi bakteri khususnya Escherichia coli pada peralatan makan yang dipakai dan total coliform pada air pencucian peralatan makan tersebut. Sehingga diharapkan dengan dilakukannya penelitian ini dapat diketahui potensi penularan penyakit dari peralatan makan dan air pencucian di Pujasera X.

\section{Metode Penelitian}

Metode penelitian in dilakukan secara analisis deskriptif dimana hal pertama yang dilakukan adalah menentukan jumlah sampel yang akan diperiksa. Selanjutnya pengambilan data primer, pemeriksaan di laboratorium, pengolahan data dan analisis secara deskriptif.

\section{Penentuan Jumlah Sampel}

Populasi dari penelitian ini adalah seluruh tenant makanan yang ada di Pujasera $\mathrm{X}$ yang berdasarkan wawancara dan observasi, terdapat 2 tenant. Objek dari penelitian ini adalah kualitas mikrobiologis air air bersih, peralatan makan dan tangan penjamah makanan.

Menurut Gay yang dikutip dari ref. [5], bahwa semakin banyak jumlah sampel makan akan semakin representatif hasilnya. Selain itu, jumlah sampel juga dapat ditentukan berdasarkan jenis penelitian yang dilakukan. Penelitian deskriptif, sampel minimumnya adalah $10 \%$ populasi atau $20 \%$ populasi jika populasinya sangat sedikit.

Maka berdasarkan uraian di atas, sampel yang diambil untuk masing-masing peralatan makan dari setiap tenant adalah $20 \%$ dari rata-rata jumlah pengunjung karena penelitian yang direncanakan bersifat deskriptif. Berikut adalah rincian sampel:

1. Air bersih sebanyak $500 \mathrm{ml}[6]$ dari 2 tenant.

2. Tenant 1 dengan penjualan rata-rata per hari sebanyak 8 piring, sehingga sampel yang diambil sebanyak 2.

3. Tenant 2 dengan penjualan rata-rata penjualan per hari dari makanan jenis warteg (sudah dimasak terlebih dahulu) sebanyak 38 piring sehingga sampel piring yang diambil adalah 8 .

4. Sampel swab masing-masing penjamah makanan dari dua tenant.

Data yang diambil pada penelitian ini merupakan data primer yaitu data yang diperoleh langsung dari sumber data, yang diperoleh dengan cara observasi dan wawancara keadaan tempat pengambilan sampel dan uji laboratorium. Data primer yang diharapkan dari tugas akhir ini adalah kualitas mikrobiologis air, piring, dan tangan penjamah makan.

\section{Uji Laboratorium Hasil Pengambilan Sampel}

Sampel air pencuci dan peralatan makan kemudian dianalisis di laboratorium. Sampel air bersih diuji dengan menggunakan metode JPT bakteri Total Coliform dan sampel usap peralatan makan dan tangan penjamah makan menggunakan metode swab untuk mengetahui keberadaan bakteri Escherichia coli.

\section{Pengolahan Data dan Analisis Deskriptif}

Hasil pemeriksaan laboratorium air bersih dijabarkan dan dibandingkan dengan baku mutu yaitu Peraturan Menteri Kesehatan Nomor 416 Tahun 1990 Tentang Syarat-syarat \& Pengawasan Kualitas Air Minum. Sementara peralatan makan dijabarkan dan dibandingkan dengan baku mutu yaitu Peraturan Menteri Kesehatan Nomor 1098 Tahun 2003 tentang Persyaratan Higiene Sanitasi Rumah Makan dan Restoran, kemudian dianalisis secara deskriptif. 


\section{Hasil dan Pembahasan}

Dalam penelitian ini akan dibahas hasil dari pemeriksaan sampel air, piring, sendok, dan tangan kemudian dibandingkan dengan peraturan yang berlaku kemudian dianalisis secara deskriptif. Secara umum, alur penelitian yang dilakukan dapat dilihat pada Gambar 1.

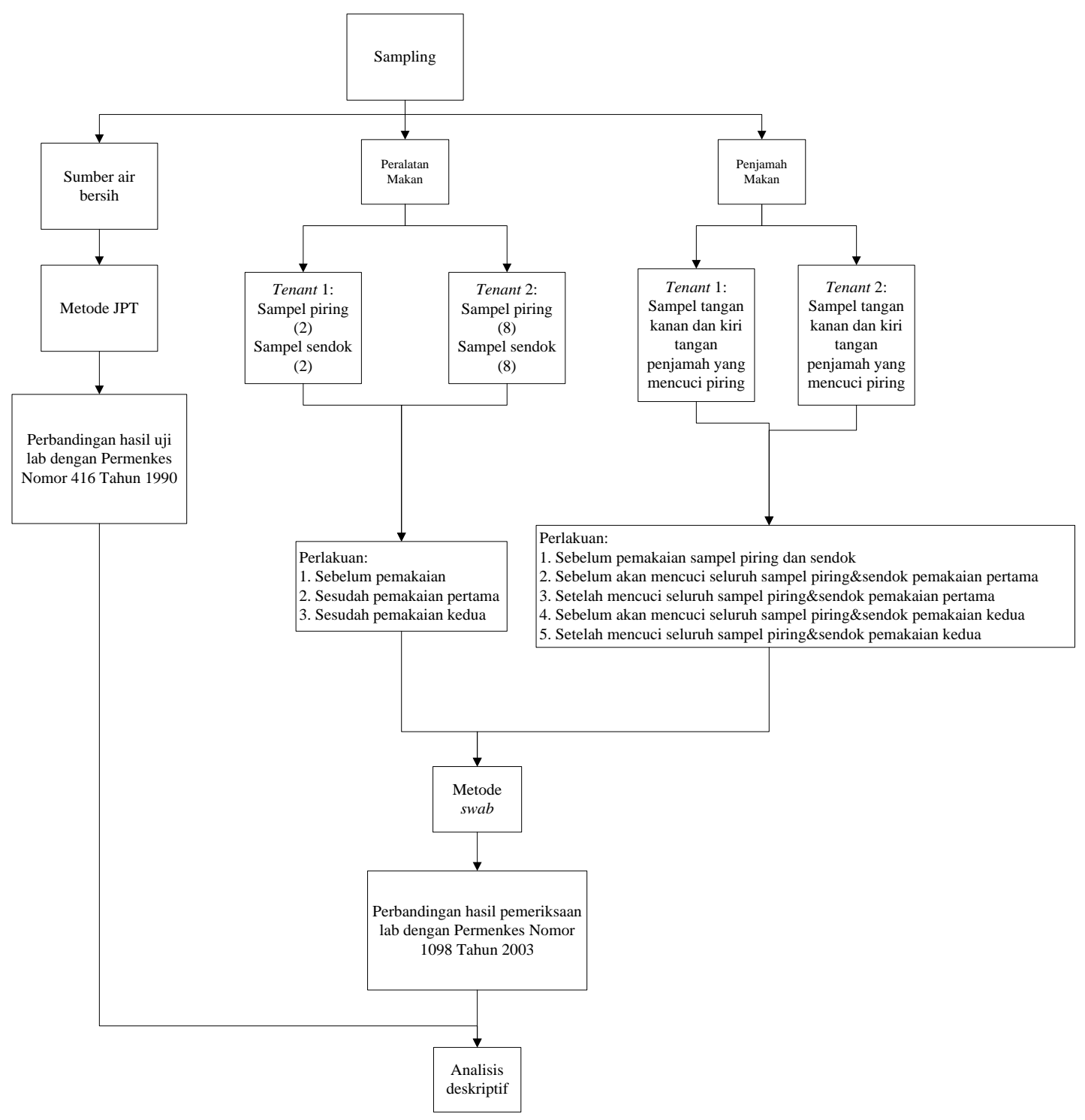

Gambar 1. Alur penelitian

Sumber: Hasil analisis, 2019

\section{Pemeriksaan Air}

Sumber air pencucian di kedua tenant di Pujasera $\mathrm{X}$ merupakan air sumur artesis dengan kedalaman 150-200 meter. Pengambilan sampel dilakukan dari air keran masing-masing tenant yang menjadi tempat pencucian peralatan makan. Kedua tenant memiliki keran masing-masing yang dipakai untuk mencuci namun dengan sumber air yang sama. Berdasarkan hasil pemeriksaan di laboratorium terhadap sampel air bersih di 2 tenant yang telah dilakukan, terdapat adanya bakteri coliform pada kedua sampel air dan tidak ditemukan Escherichia coli pada kedua sampel air. Pada Tabel 1 dapat dilihat rincian hasil pemeriksaan kualitas bakteriologis air di kedua tenant.

Tabel 1. Hasil pemeriksaan kualitas bakteriologis air

\begin{tabular}{ccc}
\hline Jenis Sampel & JPT (jumlah/100ml air) & Escherichia coli \\
\hline Tenant 1 & 79 & Negatif \\
Tenant 2 & 79 & Negatif \\
\hline
\end{tabular}

Sumber: Hasil penelitian, 2019 
Sesuai dengan Peraturan Menteri Kesehatan Nomor 416 Tahun 1990 tentang Syarat-Syarat dan Pengawasan Kualitas Air, dimana untuk persyararatan kualitas air bukan perpipaan kadar maksimum total coliform yang diperbolehkan adalah 50/100 ml. Hasil ini menunjukkan air bersih yang digunakan untuk mencuci peralatan makan di Pujasera ini tidak memenuhi baku mutu yang ada. Menurut ref. [7], keberadaan total coliform ini sangat umum di alam (tanah atau vegetasi) dan secara umum tidak berbahaya. Namun, keberadaannya menjadi indikator dari keberadaan patogen lainnya dan mengindikasikan adanya kontaminasi. Menurut ref. [8], keberadaan total coliform tanpa adanya keberadaan Escherichia coli pada air kemungkinan besar disebabkan oleh kontaminasi dari alam, saat konstruksi atau saat perbaikan perpipaan. Karena sumber air pada Pujasera X merupakan air artesis, maka sumber kontaminan coliform pada air adalah dari alam yaitu tanah. Kebanyakan bakteri coliform tidak menyebabkan penyakit pada manusia. Namun, bakteri ini dijadikan sebagai indikator pada air karena keberadaannya dapat mengindikasi adanya bakteri penyebab penyakit (patogen).

Tidak adanya Escherichia coli pada air menandakan bahwa air tidak terkontaminasi tinja manusia atau tinja hewan berdarah panas lainnya. Menurut ref. [9], coliform dijadikan sebagai indikator bagi kelompok bakteri patogen karena didasarkan kepada sifatnya yaitu; tidak patogen, berada di air apabila bakteri patogen lain juga ada atau mungkin sekali ada dan dalam jumlah yang jauh lebih besar, jumlah bakteri indikator dapat dikorelasikan dengan probabilitas adanya kuman patogen, mudah, cepat dikenali, pengujian laboratorium yang murah, dapat dikuantifikasi secara laboratoris, dan dapat bertahan lebih lama daripada bakteri patogen di dalam lingkungan yang tidak menguntungkan.

\section{Pemeriksaan Alat}

Pengambilan sampel pada peralatan makan (piring dan sendok) di Pujasera X dilakukan dengan metode $s w a b$ sesuai dengan petunjuk pemeriksaan oleh Departemen Kesehatan. Sampel piring dan sendok yang diambil di tenant 1 berjumlah masing-masing 2 sementara untuk tenant 2 masing-masing 8 . Pengambilan sampel dilakukan saat sebelum pemakaian piring dan sendok oleh konsumen, setelah pencucian pemakaian pertama oleh konsumen, dan setelah pencucian pemakaian kedua oleh konsumen.

Berdasarkan hasil pemeriksaan laboratorium peralatan makan menggunakan metode swab di tenant 1 tidak ditemukan adanya bakteri Escherichia coli, baik pada piring maupun sendok, baik sebelum pencucian maupun setelah pencucian pertama dan kedua. Sementara pada pemeriksaan peralatan makan di tenant 2, ditemukan keberadaan Escherichia coli pada piring 1 sebelum pemakaian. Hasil pemeriksaan peralatan makan di tenant 1 dapat dilihat pada Tabel 2.

Hasil ini sesuai dengan penelitian yang dilakukan oleh ref. [10] pada rumah makan Kompleks Wanea Plaza, Kota Manado. Dari 3 warung makan yang diteliti, terdapat 1 warung (RM. Y) yang seluruh sampel peralatan makannya baik piring, sendok, garpu maupun gelas baik sebelum, dan setelah pemakaian tidak positif Escherichia coli dan 1 warung lainnya (RM. Z) pada sampel peralatan makan yaitu gelas sebelum pemakaian positif Escherichia coli dan negatif Escherichia coli setelah pencucian.

Tabel 2. Hasil pengamatan Escherichia coli pada peralatan makan

\begin{tabular}{lccc}
\hline \multicolumn{1}{c}{ Kategori } & $\begin{array}{c}\text { Positif Escherichia coli } \\
\text { Sebelum Pemakaian }\end{array}$ & $\begin{array}{c}\text { Positif Escherichia coli } \\
\text { Sesudah Pencucian } \\
\text { Pemakaian Pertama }\end{array}$ & $\begin{array}{c}\text { Positif Escherichia coli } \\
\text { Sesudah Pencucian } \\
\text { Pemakaian Kedua }\end{array}$ \\
\hline Piring tenant 1 & - & - & - \\
Piring tenant 2 & 1 dari 8 piring & - & - \\
Sendok tenant 1 & - & - & - \\
Sendok tenant 2 & - & - & - \\
\hline
\end{tabular}

Sumber: Hasil penelitian, 2019

Sementara pada penelitian lain yang dilakukan oleh ref. [11] dari 11 rumah makan di Pasar Petisah Medan dari sampel piring, gelas, dan sendok diambil, dari seluruh sampel menunjukkan negatif Escherichia coli. Begitupun dengan penelitian yang dilakukan oleh ref. [12], dimana seluruh sampel peralatan makan yang diteliti di 5 kantin seluruhnya negatif Escherichia coli.

Hasil ini menunjukkan bahwa piring 1 sebelum pemakaian pada tenant 2 tidak memenuhi baku mutu dari Peraturan Menteri Kesehatan nomor 1098 Tahun 2003 tentang Persyaratan Higiene Sanitasi Rumah Makan dan Restoran, dimana peralatan makan yang kontak langsung dengan makanan yang siap disajikan tidak boleh mengandung Escherichia coli per $\mathrm{cm}^{2}$ alat. Sementara pada tenant 1 seluruh piring dan sendok telah memenuhi standar baku mutu yang ditetapkan. 


\section{Pemeriksaan Tangan Penjamah}

Pemeriksaan tangan penjamah dilakukan 3 kali yaitu pada saat sebelum pemakaian piring pertama, sebelum pencucian pemakaian pertama, sesudah pencucian pemakaian pertama, sebelum pencucian pemakaian kedua dan pada saat sesudah pencucian pemakaian kedua. Adapun metode yang digunakan dalam pemeriksaan tangan penjamah adalah metode swab.

Hasil pemeriksaan laboratorium tangan penjamah di tenant 1, tidak ditemukan adanya bakteri Escherichia coli baik sebelum pemakaian piring pertama, sebelum pencucian pemakaian piring pertama, setelah pencucian pemakaian piring pertama, sebelum pencucian pemakaian piring kedua, dan setelah pencucian pemakaian piring kedua. Sementara pada pemeriksaan tangan penjamah di tenant 2, ditemukan adanya Escherichia coli pada tangan penjamah sebelum pemakaian piring pertama. Sementara sisanya tidak ditemukan. Hasil pemeriksaan pada tangan penjamah makan di tenant 1 dan tenant 2 dapat dilihat pada Tabel 3.

Tabel 3. Hasil Pengamatan Escherichia coli Tenant 1 pada Tangan Penjamah

\begin{tabular}{|c|c|c|c|c|c|}
\hline Kategori & $\begin{array}{l}\text { Sebelum } \\
\text { Pemakaian } \\
\text { Pertama }\end{array}$ & $\begin{array}{l}\text { Sebelum } \\
\text { Pencucian } \\
\text { Pemakaian } \\
\text { Pertama }\end{array}$ & $\begin{array}{c}\text { Sesudah } \\
\text { Pencucian } \\
\text { Pemakaian } \\
\text { Pertama }\end{array}$ & $\begin{array}{c}\text { Sebelum } \\
\text { Pencucian } \\
\text { Pemakaian } \\
\text { Kedua } \\
\end{array}$ & $\begin{array}{c}\text { Sesudah } \\
\text { Pencucian } \\
\text { Pemakaian } \\
\text { Kedua } \\
\end{array}$ \\
\hline $\begin{array}{c}\text { Tangan } \\
\text { Penjamah } 1\end{array}$ & - & - & - & - & - \\
\hline $\begin{array}{c}\text { Tangan } \\
\text { Penjamah } 2\end{array}$ & + & - & - & - & - \\
\hline
\end{tabular}

Sumber: Hasil penelitian, 2019

Hasil penelitian ref. [13] pada penjamah makanan di Rumah Sakit Palembang menunjukkan hasil dari 30 sampel tangan, 5 diantaranya negatif Escherichia coli sementara 25 lainnya positif. Ref. [14], dari 16 sampel penjamah makan di PT Pelita Sejahtera Abadi Kota Bandung, 8 sampel teridentifikasi positif Escherichia coli sementara 8 lainnya negatif. Sementara pada penelitian yang dilakukan oleh ref. [15], dari 14 sampel tangan penjamah yang diambil dari 14 rumah makan lalapan di Langowan Raya Kabupaten Minahasa keseluruhannya negatif Escherichia coli. Menurut ref. [16], salah satu media persebaran mikroorganisme patogen adalah melalui jari tangan yang dimana jari tangan dari penjamah berhubungan langsung dengan peralatan makan sehingga berpotensi untuk mengkontaminasi peralatan makan.

Keberadaan Escherichia coli ini sangat erat kaitannya dengan higienitas perorangan. Literatur melaporkan bahwa banyak kasus diare terjadi karena kontaminasi Escherichia coli dan patogen lain. Hal tersebut menunjukkan bahwa makanan telah terkontaminasi oleh tinja. Akibatnya, setiap patogen yang penularannya diketahui melalui jalur fekal-oral dapat ditularkan melaui makanan [16]. Persebaran mikroorganisme patogen dapat ditularkan dari tinja melalui jari tangan manusia, lalat, lingkungan tanah dan air yang berhubungan langsung dengan makanan yang kemudian dikonsumsi oleh konsumen.

\section{Hasil Wawancara dan Observasi}

Selain melakukan pemeriksaan di laboratorium terhadap sampel air bersih, peralatan makan dan tangan penjamah, dilakukan juga wawancara dan observasi terhadap keadaan di masing-masing tenant dan penjamah untuk melihat higiene sanitasi dari masing-masing tenant juga para penjamah untuk menunjang hasil analisis. Parameter yang diobservasi dan diwawancara dapat dilihat pada Tabel 4.

Tabel 5. Pemeriksaan kelaikan higiene sanitasi Pujasera $X$

\begin{tabular}{|c|c|c|c|c|}
\hline \multirow{2}{*}{ No } & \multirow{2}{*}{ Parameter } & & \multicolumn{2}{|c|}{ Tempat } \\
\hline & & & Tenant 1 & Tenant 2 \\
\hline \multicolumn{5}{|l|}{ Air Bersih } \\
\hline 1 & Sumber air bertekanan (mengalir) & & $\sqrt{ }$ & $\sqrt{ }$ \\
\hline 2. & Sumber air mencukupi & & $\sqrt{ }$ & $\sqrt{ }$ \\
\hline 3. & Sumber air panas & & $\mathrm{X}$ & $\mathrm{X}$ \\
\hline & Sub Total & & 2 & 2 \\
\hline \multicolumn{5}{|c|}{ Air Limbah } \\
\hline 4. & $\begin{array}{l}\text { Tempat pencucian berhubungan langsung } \\
\text { pembuangan limbah }\end{array}$ & dengan saluran & $\sqrt{ }$ & $\sqrt{ }$ \\
\hline 5. & Saluran pembuangan air limbah tertutup & & $\sqrt{ }$ & $\sqrt{ }$ \\
\hline & Sub Total & & 2 & 2 \\
\hline Tempat Sa & npah & & & \\
\hline
\end{tabular}




\begin{tabular}{|c|c|c|c|}
\hline \multirow{2}{*}{ No } & \multirow{2}{*}{ Parameter } & \multicolumn{2}{|c|}{ Tempat } \\
\hline & & Tenant 1 & Tenant 2 \\
\hline 6. & Tempat sampah tertutup & $\mathrm{X}$ & $\mathrm{X}$ \\
\hline 7. & Tempat sampah kedap air & $\sqrt{ }$ & $\sqrt{ }$ \\
\hline 8. & Tempat sampah diangkut dalam 24 jam & $\sqrt{ }$ & $\sqrt{ }$ \\
\hline 9. & $\begin{array}{l}\text { Tempat sampah tidak berada dekat dengan tempat penyimpanan } \\
\text { peralatan }\end{array}$ & X & X \\
\hline & Sub Total & 2 & 2 \\
\hline \multicolumn{4}{|c|}{ Pencucian Peralatan } \\
\hline 10. & Sisa makanan dibuang sebelum pencucian & $\sqrt{ }$ & $\sqrt{ }$ \\
\hline 11. & Terdapat 3 bak pencucian (pengguyuran, penyabunan, pembilasan) & $\mathrm{X}$ & $\mathrm{X}$ \\
\hline 12. & $\begin{array}{l}\text { Proses pencucian melalui tahap pangguyuran, penyabunan dan } \\
\text { pembilasan }\end{array}$ & $\sqrt{ }$ & $\sqrt{ }$ \\
\hline 13. & Menggunakan air panas saat pencucian & $\mathrm{X}$ & $\mathrm{X}$ \\
\hline 14. & Pengeringan peralatan setelah dicuci dikeringkan secara alami & $\sqrt{ }$ & $\sqrt{ }$ \\
\hline & Sub Total & 3 & 3 \\
\hline \multicolumn{4}{|c|}{ Tempat Penyimpanan Peralatan } \\
\hline 15. & Rak-rak penyimpanan peralatan anti karat & $\sqrt{ }$ & $\sqrt{ }$ \\
\hline 16. & $\begin{array}{l}\text { Penyimpanan peralatan terlindung dari sumber } \\
\text { pengotoran/kontaminasi } \\
\text { Sub Total }\end{array}$ & $\sqrt{ }$ & X \\
\hline \multicolumn{4}{|c|}{ Higiene Sanitasi Penjamah } \\
\hline & Selalu mencuci tangan sebelum bekerja & $\mathrm{X}$ & $\mathrm{X}$ \\
\hline & Selalu mencuci tangan setelah memegang benda lain & $\mathrm{X}$ & $\mathrm{X}$ \\
\hline & Setelah mencuci tangan keringkan dengan lap & $\sqrt{ }$ & $\sqrt{ }$ \\
\hline 20. & Selalu mencuci tangan dengan setelah dari toilet & $\sqrt{ }$ & $\sqrt{ }$ \\
\hline 21. & Selalu mencuci tangan dengan sabun setelah dari toilet & $\mathrm{X}$ & $\mathrm{X}$ \\
\hline & Sub Total & 2 & 2 \\
\hline & Total & 13 & 12 \\
\hline & Persentase & $61,9 \%$ & $57,1 \%$ \\
\hline
\end{tabular}

Sumber: Hasil analisis, 2019

Hasil dari Tabel 4 didapatkan bahwa tenant 1 memenuhi 13 dari 21 parameter yang dibuat. Maka dari itu, tenant 1 mendapatkan skor sebesar 13/21 x 100\% =61,9\%. Sementara untuk tenant 2 memenuhi 12 dari 21 parameter yang dibuat, maka dari itu tenant 2 mendapatkan skor sebesar 12/21 x 100\%= $57,1 \%$. Hasil pemeriksaan ini menunjukkan bahwa kedua tenant belum sepenuhnya memenuhi kelayakan higiene, sehingga perlu adanya upaya dari kedua tenant untuk memenuhinya seperti menyediakan 3 bak pencucian, menyediakan sumber air panas untuk pencucian, menyediakan tempat penyimpanan peralatan tertutup, menyediakan tempat sampah yang tertutup, dan merubah kebiasaan cuci tangan penjamah.

\section{Air Bersih dan Air Limbah}

Berdasarkan hasil observasi, sumber air bersih yang digunakan untuk pencucian di Pujasera $\mathrm{X}$ merupakan air yang bertekenan atau mengalir. Menurut penelitian yang dilakukan oleh ref. [17], teknik pencucian dengan menggunakan air mengalir dapat menekan angka kuman pada peralatan makan dibandingkan dengan pencucian dengan air yang tidak mengalir. Menurut ref. [18], pencucian dengan menampung air bersih di dalam ember dan digunakan berulang kali akan lebih memungkinkan kontaminasi bakteri. Hal ini karena bakteri dan kontaminan-kontaminan dari peralatan makan sebelumnya berkumpul di air pencucian sehingga membuat air tidak bersih dan layak lagi digunakan untuk mencuci peralatan makan. Dengan digunakannya air mengalir dari keran untuk mencuci peralatan, air mengalir yang dipakai adalah air yang bersih dan belum dipakai untuk mencuci apapun sebelumnya. Pujasera X telah mengurangi resiko kontaminasi bakteri yang terjadi akibat air pencucian. Dari hasil wawancara dan observasi juga didapatkan bahwa kuantitas air yang didapatkan di kedua tenant Pujasera X mencukupi untuk kebutuhan mencuci peralatan dan makanan. Cukupnya kuantitas air ini baik karena akan membuat pencucian di kedua tenant tidak menumpuk dan menjadi maksimal.

Bak pencucian pada kedua tenant langsung dihubungkan dengan saluran pembuangan air limbah yang tertutup. Hal ini sudah baik karena menurut ref. [19] yang dikutip dari ref. [20] air limbah yang pembuangannya tidak melalui pengolahan terlebih dahulu dapat menyebabkan gangguan pada kesehatan dan lingkungan hidup diantaranya, yaitu sebagai media dalam penyebaran berbagai penyakit, media berkembangbiaknya mikroorganisme patogen, tempat berkembangbiak bagi nyamuk dan tempat hidup larva nyamuk, mengakibatkan bau dan pandangan yang tidak sedap. Sehingga saluran pembuangan air 
limbah yang terhubung langsung dengan tempat pencucian peralatan secara tertutup dapat menghindari resiko terjadinya hal-hal tersebut.

\section{Cara Pencucian}

Hasil observasi yang dilakukan terhadap tenant 1 dan tenant 2 didapatkan bahwa cara pencucian dikedua tenant sama dimana hal yang pertama dilakukan adalah membersihkan sisa makanan. Tenant 1 membuang sisa makanannya langsung dari piring ke tempat sampah, sementara tenant 2 mengumpulkan sisa makanannya terlebih dahulu di suatu wadah lalu kemudian dibuang ke tempat sampah. Kedua tempat sampah berada di bawah tempat pencucian. Hal yang dilakukan setelah itu adalah mengguyur peralatan dengan air keran yang mengalir dan sudah bersih dari sisa makanan dengan air, kemudian menyabuninya dengan sabun/detergen, terakhir dilakukan pembilasan dari busa sabun. Keseluruhan pencucian ini dilakukan dalam satu bak pencucian sementara dalam Permenkes nomor 1098 Tahun 2003 sedikitnya harus ada 3 bak pencucian masing-masing untuk mengguyur, menyabun dan membilas. Menurut Permenkes nomor 1098 tahun 2003 juga disebutkan bahwa air untuk keperluan pencucian harus dilengkapi dengan air panas dengan suhu $40^{\circ} \mathrm{C}-80^{\circ} \mathrm{C}$. Bakteri sangatlah sensitif terhadap panas dan sangat cepat terbunuh pada suhu di atas $65^{\circ} \mathrm{C}$, virus akan mati pada suhu sekitar $60^{\circ} \mathrm{C}-65^{\circ} \mathrm{C}$, tetapi lebih lambat terbunuh daripada bakteri sehingga WHO (2015) menyarankan untuk memanaskan air untuk membunuh bakteri patogen, virus dan protozoa.

\section{Tempat Penyimpanan}

Berdasarkan hasil observasi, setelah dilakukan pencucian peralatan makan ditiriskan di rak penyimpanan. Kedua tenant melakukan pengeringan peralatan dengan cara dikeringkan dengan alami, tanpa dilap dengan kain ataupun tisu. Hal ini sudah sesuai dengan Permenkes nomor 1098 Tahun 2003 dimana pengeringan peralatan harus ditiriskan pada rak-rak anti karat sampai kering sendiri dan tidak boleh dilap dengan kain. Menurut ref. [21] kain lap untuk mengeringkan peralatan makan yang tidak sering diganti dapat menjadi titik kritis cemaran bakteriologis dan dapat mengkontaminasi kuman yang berada pada peralatan makan. Sementara Depkes RI (2006) dalam ref. [11] menyebutkan penggunaan lap setelah pencucian alat tidak boleh dilakukan karena dapat menjadi sumber pencemaran sekunder. Pemakaian lap boleh dilakukan asalkan lap yang digunakan steril dan sering diganti, dan yang paling baik adalah lap yang penggunaannya sekali pakai (single use). Rak-rak yang digunakan oleh kedua tenant untuk menaruh dan mengeringkan peralatan makan setelah dicuci merupakan rak yang terbuka sehingga beresiko adanya pencemaran dari serangga, lalat, tikus dan hewan lainnya.

\section{Tempat Sampah}

Tempat pembuangan sampah dan sisa makanan pada kedua tenant terletak di bawah tempat pencucain peralatan, hal ini guna memudahkan penjamah makan dalam membuang sisa-sisa makanan sebelum peralatan makan dicuci. Berdasarkan hasil observasi yang dilakukan, tempat sampah yang digunakan pada kedua tenant kedap air, dimana bak sampah dilapisi dengan plastik. Namun, tempat sampah dikedua tenant tidak tertutup. Tempat sampah yang tidak bertututp memiliki resiko yang tinggi untuk menularkan bakteri [22]. Hal ini dapat menjadi salah satu sumber penularan patogen karena keberadaan sampah yang tidak ditutup dapat mengundang lalat yang menjadi salah satu vektor foodborne disease [23].

Menurut Notoatmodjo (2003) dalam ref. [20] sampah berkaitan erat dengan kondisi kesehatan masyarakat dimana dalam sampah di dalamnya hidup berbagai mikroorganisme penyebab penyakit atau bakteri patogen dan juga serangga yang menjadi vektor penyakit. Sehingga seharusnya tempat sampah di Pujasera $\mathrm{X}$ haruslah bersifat tertutup untuk menghindari resiko penyebaran penyakit yang terjadi akibat sampah. Untuk pengangkutan sampah di Pujasera X diangkut setiap harinya, hal ini sudah sesuai dengan Permenkes nomor 1098 Tahun 2003 dimana sampah sudah harus dibuang dalam waktu 24 jam, sehingga mengurangi resiko penumpukan sampah dan pembusukan sampah yang makin meningkatkan resiko kontaminasi akibat sampah karena partumbuhan mikroorganisme akibat pembusukan.

\section{Higiene Sanitasi Penjamah}

Berdasarkan observasi dan wawancara, penjamah di kedua tenant tidak selalu mencuci tangan mereka sebelum akan bekerja. Namun, setelah mencuci tangan kerap kali mereka mengelap tangannya di lap yang sudah berulang kali dipakai atau mengelapnya ke celemek yang dipakai. Lap yang telah dipakai berulang kali merupakan sumber berkumpulnya bakteri. Sama halnya dengan lap untuk mengeringkan piring, menurut Depkes RI (2006) dalam ref. [11] menyebutkan penggunaan lap setelah pencucian alat tidak boleh dilakukan karena dapat menjadi sumber pencemaran sekunder. Pemakaian lap boleh dilakukan asalkan lap yang digunakan steril dan sering diganti dan yang paling baik adalah lap yang penggunaannya sekali pakai (single use). Berdasarkan wawancara, kedua penjamah mencuci tanganya tiap kali dari toilet, namun tidak selalu mencucinya dengan sabun dikarenakan tidak selalu tersedianya 
sabun di wastafel toilet Pujasera X. Hal ini belum baik karena aktifitas dari toilet merupakan aktifitas yang berhubungan langsung dengan sumber Escherichia coli. Namun akan lebih baik jika penjamah mencucinya dengan sabun.

\section{Keberadaan Coliform dan Escherichia coli}

Berdasarkan hasil pemeriksaan di laboratorium didapatkan bahwa kedua sampel air di tenant 1 dan tenant 2 mengandung angka total coliform melebihi baku mutu, namun tidak terdapat Escherichia coli. Coliform pada sumber air kemungkinan besar disebabkan oleh kontaminasi dari alam (tanah atau vegetasi), saat konstruksi atau saat perbaikan perpipaan. Sementara pada pemeriksaan peralatan makan, ditemukan Escherichia coli pada sampel piring 1 sebelum pemakaian di tenant 2 dan pada sampel tangan penjamah sebelum penyajian pada piring sebelum pemakaian di tenant 2. Keberadaan Escherichia coli pada piring 1 sebelum pemakaian di tenant 2 tersebut dapat disimpulkan bukan berasal dari air pencucian karena dari hasil pemeriksaan air tidak ditemukan Escherichia coli pada air pencuciannya. Coliform pada sumber air bersih yang melebihi baku mutu beresiko untuk menyebabkan sakit pada konsumen karena kehadiran coliform merupakan indikator kemungkinan adanya patogen dalam air, sehingga semakin tinggi angka coliform maka semakin tinggi pula kemungkinan adanya patogen dalam air. Kehadiran Escherichia coli pada piring 1 di tenant 2 sebelum pemakaian menandakan bahwa piring telah terkontaminasi tinja manusia atau hewan berdarah panas lainnya [24] dan menunjukkan adanya praktik sanitasi yang kurang baik. Adanya Escherichia coli pada piring 1 sebelum pemakaian pertama di tenant 2 dapat beresiko kepada konsumen karena Escherichia coli merupakan bakteri indikator kehadiran patogen penyebab penyakit seperti bakteri, virus dan parasit [25].

Faktor-faktor yang menyebabkan adanya kontaminasi bakteri pada piring dapat berasal dari pencucian peralatan yang kurang bersih, tidak mencuci dengan air hangat, serta tidak adanya 3 bak pencucian peralatan (mengguyur, menyabun, dan membilas) [26]. Berdasarkan hasil observasi yang dilakukan, kedua tenant tidak mencuci peralatan dengan air panas yang dapat membunuh bakteri pada suhu $65^{\circ} \mathrm{C}$, kedua tenant hanya menggunakan air dingin untuk mencuci seluruh peralatan makan.

Faktor lain yang dapat menyebabkan positif Escherichia coli adalah jari tangan dan lalat sebagaimana yang disebutkan oleh WHO (2006) dimana jari tangan dan lalat merupakan media penyebaran mikroorganisme patogen. Tangan penjamah dapat menjadi salah satu faktor terbesar dari kontaminasi Escherichia coli pada piring karena berdasarkan hasil observasi dan wawancara, penjamah tidak selalu mencuci tangannya saat akan menjamu atau memasak, dan jika penjamah mencuci tangan pun kerap kali tangan dilap dengan lap yang sudah sering dipakai atau mengelap tangannya ke celemek. Pemakaian lap boleh dilakukan asalkan lap yang digunakan steril dan sering diganti dan yang paling baik adalah lap yang penggunaannya sekali pakai (single use) [11].

Berdasarkan hasil observasi, tempat sampah yang dapat menjadi sarang bagi lalat berada di bawah tempat pencucian dan dekat dengan rak tempat pengeringan peralatan setelah dicuci, sehingga hal tersebut beresiko untuk menjadi sarang lalat. Tempat sampah yang letaknya berdekatan dengan rak-rak peralatan makan sangat beresiko mengkontaminasi peralatan yang bersih [22]. Lalat dapat menyebarkan berbagai jenis foodborne diseases diantaranya diare, disentri, muntaber, thypus, dan lain-lain. Lalat mentransmisikan agen penyakit dengan cara hinggap di makanan, lewat muntahan, kotoran, maupun hanya memindahkan kotoran yang ada di permukaan tubuhnya [23]. Skema kemungkinan keberadaan Escherichia coli pada peralatan makan dapat dilihat pada Gambar 2.

Berdasarkan hasil pemeriksaan di laboratorium, ditemukan bakteri Escherichia coli positif pada tangan penjamah tenant 2 sebelum melakukan penyajian terhadap pemakaian pertama sampel piring. Faktor-faktor yang dapat mempengaruhi keberadaan Escherichia coli pada tangan penjamah tersebut adalah karena higiene sanitasi perseorangan yang belum baik. Berdasarkan hasil wawancara terhadap kedua penjamah di kedua tenant, kebiasaan mencuci tangan menggunakan mereka lakukan setelah dari toilet, tetapi terkadang tidak menggunakan sabun. Hal ini sangat penting dilakukan karena aktifitas di toilet sangat berhubungan erat dengan Escherichia coli dimana bakteri tersebut berasal dari tinja manusia sehingga jika penjamah tidak mencuci tangannya dengan baik dan tidak menggunakan sabun (desinfektan) setelah dari toilet, kemungkinan tangan penjamah terkontaminasi Escherichia coli sangat besar. 


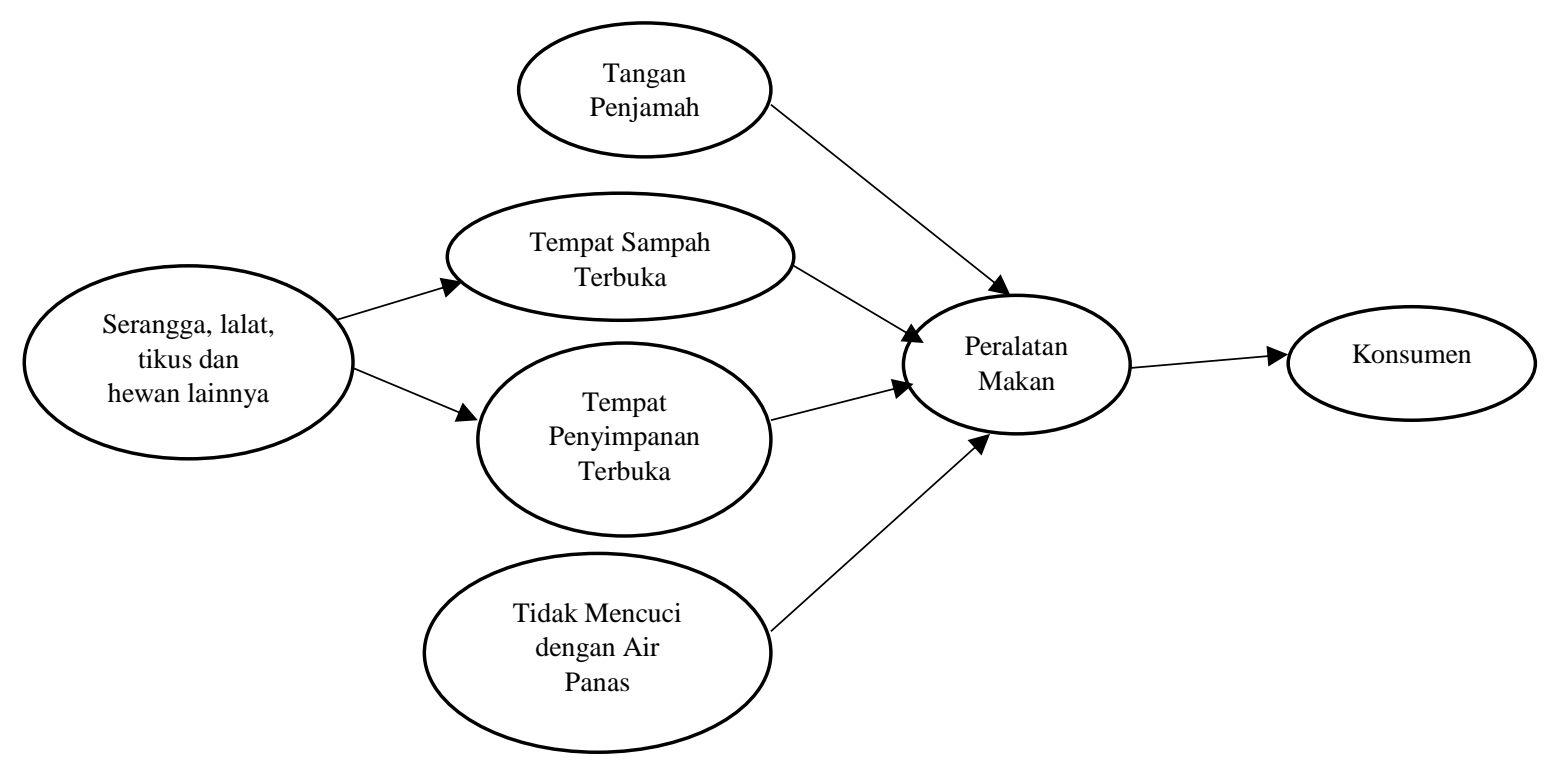

Gambar 2. Skema peluang keberadaan Escherichia coli pada peralatan makan

Sumber: Hasil analisis, 2019

Berdasarkan observasi dan wawancara didapatkan bahwa kedua penjamah tidak selalu mencuci tangan tiap akan bekerja, kedua pekerja ini melakukan cuci tangan dengan tidak tentu. Penjamah kadang mencuci tangannya saat akan menjamu konsumen, namun kerap kali tidak. Selain itu, penjamah juga kadang mencuci tangannya saat akan memasak namun kadang juga tidak. Saat setelah mencuci tangan, kerap kali mereka mengeringkan tangan mereka dengan lap yang dipakai berulang kali atau mengelapnya ke celemek yang mereka gunakan. Sehingga faktor yang memungkinan ditemukannya Escherichia coli pada tangan penjamah tenant 2 adalah kemungkinan cara mencuci tangan yang belum baik, tidak selalu dilakukannya cuci tangan tiap akan bekerja dan tidak memakai sabun setelah dari toilet, atau melalui media lain seperti memegang benda-benda yang telah terkontaminasi Escherichia coli. Menurut ref. [27] Escherichia coli dapat berpindah secara pasif lewat makanan, air, susu, dan produk-produk lainnya.

\section{Kesimpulan}

Kualitas bakteriologis air bersih pencucian di kedua tenant di Pujasera $\mathrm{X}$ berdasarkan hasil pemeriksaan laboratorium total coliform adalah 79/100 $\mathrm{ml}$ untuk tenant 1 dan 2 . Hasil pemeriksaan ini melebihi baku mutu yang ditetapkan oleh Permenkes Nomor 416 Tahun 2010 tentang syarat-syarat dan pengawasan kualitas air dimana untuk air bersih yang berasal dari bukan perpipaan kadar maksimul total coliform adalah 50/100 ml air. Berdasarkan hasil pemeriksaan swab peralatan makan (piring dan sendok), terdapat bakteri Escherichia coli pada sampel piring 1 di tenant 2 sebelum pemakaian. Hal tersebut tidak memenuhi syarat Permenkes nomor 1098 Tahun 2003 tentang persyaratan higiene sanitasi rumah makan dan restoran dimana peralatan makan yang kontak langsung dengan makanan yang disajikan tidak diperbolehkan mengandung Escherichia coli per $\mathrm{cm} 2$ permukaan alat. Sementara itu, hasil swab tangan penjamah, ditemukan Escherichia coli pada tangan penjamah tenant 2 pada saat sebelum melakukan penyajian pada sampel piring 1. Keberadaan Escherichia coli pada piring kemungkinan berasal dari tangan penjamah, lalat yang berasal dari tempat sampah yang terbuka, tempat penyimpanan yang terbuka, dan tidak dilakukannya pencucian dengan air panas.

Keberadaan Escherichia coli pada tangan penjamah kemungkinan berasal dari kebiasaan mencuci tangan penjamah. Sumber air pencucian di Pujasera X, lalat dari tempat sampah, tangan penjamah, tempat penyimpanan peralatan yang tidak tertutup beresiko melunarkan penyakit pada konsumen. Berdasarkan pemeriksaan kelaikan higiene sanitasi Pujasera X yang dilakukan pada kedua tenant, higiene sanitasi penjamah dan fisik tenant 1 baru memenuhi 61,9\% kelayakan dan tenant 2 baru memenuhi 57,1\% kelayakan.

\section{Referensi}

[1] A.S. Marsanti, dan R. Widiarini, Buku Ajar Higiene Sanitasi Makanan, 2018.

[2] Peraturan Menteri Kesehatan nomor 1098 tentang Persyaratan Hygiene Sanitasi Rumah Makan dan Restoran, 2003. 
[3] A.G. Torres, M.M. Arenas-Hernandez dan Y. Martinez-Laguna, "Pathogenic Escherichia coli in Latin America," A. G. Torres (Ed.), 2010.

[4] Syarat-syarat Dan Pengawasan Kualitas Air, 1990.

[5] C. G. Sevilla, J. A. Ochave, T. G. Punsulan, B. P. Regala dan G. G. Uriarte, Pengantar Metode Penelitian (A. Tuwu, Trans.). Penerbit Universitas Indonesia (UI-Press), Jakarta, 1993.

[6] G. Alaerts dan S. S. Santika, Metoda Penelitian Air, Usaha Nasional, Surabaya, 1984.

[7] Washington State Department of Health, Coliform Bacteria and Drinking Water, 2016.

[8] Minnesota Department of Health, Coliform Bacteria, 2019.

[9] J. Soemirat, Kesehatan Lingkunngan, 2011.

[10] G. V. Mandas, O. J. Sumampouw dan O. R. Pinontoan, "Fasilitas Sanitasi Dan Pemeriksaan Escherichia Coli Pada Peralatan Makanan Yang Digunakan Di Rumah Makan Kompleks Wanea Plaza Kota Manado 7," 2018.

[11] D. Pohan, Pemeriksaan Escherichia Coli pada Usapan Peralatan Makan yang Digunakan oleh Pedagang Makanan di Pasar Petisah Medan, 2009.

[12] S. Rahmawati, A. U. Farahdiba, O. Alfan, dan R. B. Adhly, Identifikasi Total Coliform, E.Coli dan Salmonella spp. Sebagai Indikator Sanitasi Makanan Kantin di Lingkungan Kampus Terpadu Universitas Islam Indonesia, 2018.

[13] S. Utari, I. Saleh dan R. Pambayun, Bacterial Contamination of Food Handlers in X Hospital Palembang, 2018.

[14] L. P. Sugiyono dan D. N. Subandriani, Gambaran Pengetahuan, Sikap, Praktik Serta Identifikasi Bakteri Escherichia coli dan Staphylococu Aureus pada Penjamah dan Makanan di PT PSA (Pelita Sejahtera Abadi), 2014.

[15] S. V. P. Maleba, W. B. S. Joseph, dan R. H. Akili, Keberadaan Escherichia coli pada Air Bersih, Tangan Penjamah Makanan, dan Sayur Kubis RumahMakan Lalapan di Langowan Raya Kabupaten Minahasa, 2019.

[16] WHO, Penyakit Bawaan Makanan: Fokus Pendidikan Kesehatan, 2006.

[17] J. T. Azari, "Studi Komparatif Pencucian Alat Makan Dengan Perendaman Dan Air Mengalir Terhadap Jumlah Kuman Pada Alat Makan Di Warung Makan Bu Am Gonilan," 2013.

[18] F. Bobihu, Studi Sanitasi Dan Pemeriksaan Angka Kuman Pada Usapan Peralatan Makan Di Rumah Makan Kompleks Pasar Sentral Kota Gorontalo Tahun 2012, 2012.

[19] S. Notoatmodjo, Ilmu Kesehatan Masyarakat, 2003.

[20] Y. Fauzi, O. Setiani, dan M. Raharjo, Analisis Sarana Dasar Kesehatan Lingkungan yang Berhubungan dengan Kejadian Diare pada Anak Balita di Kecamatan Gading Cempaka Kota Bengkulu, 2005.

[21] A. S. Budon, Studi Kualitas Bakteriologis Air Pencucian Dan Peralatan Makan Di Kantin Uin Alauddin Makassar, Universitas Islam Negeri Alauddin Makassar, Makassar, 2013.

[22] M. P. Suryaningtyas, Sanitasi Peralatan dengan Indikator Total Mikroba dan Escherichia coli pada Warung Makan Sekitar Kampus 1 UNIMUS, Universitas Muhammadiyah Semarang, 2018

[23] D. Andiarsa, Lalat: Vektor yang Terabaikan Program?, Volume 14, 2018.

[24] H. G. Schlegel dan K. Schmidt, Mikrobiologi Umum, Gadjah Mada University Press, Yogyakarta, 1984.

[25] Government of New Brunswick, Facts On Drinking Water Coliform Bacteria - Total Coliforms \& E.Coli.

[26] Syahrizal, Hygiene Sanitasi Penjamah Makanan Terhadap Kandungan Escherichia Coli Di Peralatan Makan pada Warung Makan, 2017.

[27] D. A. Lestari, R. S. Pujiati, dan A. D. Moelyaningrum, Higiene Perorangan dan Keberadaan Bakteri Escherichia coli pada Tangan Penjual, 2015. 